\title{
The Effect of Export-Led Growth Strategy on the Ethiopian Economy
}

\author{
Hailegiorgis Biramo Allaro \\ College of Agriculture and Environmental Science, School of Agricultural Economics and Agribusiness Management, Haramaya \\ University, Ethiopia
}

\begin{abstract}
The research is aimed to scrutinise empirically the ELG (export-led growth strategy) on Ethiopia's economy. The causal relationship between export and economic growth of the country was analyzed with the application of Granger (1969) causality test using annual data for the period 1974 to 2009 . It revealed that the decline in economic growth in the country pre reform period coupled with the alarming population growth led to stagnation and even a continual decline in the income of the country. This led to closer scrutiny of export growth on economic growth to achieve a sustained economic growth. Since 1992, the economic growth policy of Ethiopian government was guided by the idea of export-led growth. The view of export-led growth conceives growth of exports as having a favorable impact on economic growth. According to this view, export expansion to foreign markets improves resource allocation and production efficiency. Export is claimed as the 'engine of growth'. The results of the study show that there is evidence of uni-directional causality between export and economic growth for Ethiopia. Export growth causes economic growth. Thus, the results are favorably comparable to those obtained in the literature (Shan and Sun, 1998).
\end{abstract}

Keywords Ethiopia, Export Performance, Economic Growth

\section{Introduction}

There are many contributors to economic growth. Export is considered as one of the very important contributors among others. In 1950s and 1960s, most of the developing countries followed the IS (import substitution) policy for their economic growth. Since the mid-1970s, in most developing countries, there has been considerable shift towards EP (export promotion strategy). This approach postulates that export expansion leads to better resource allocation, creating economies of scale and production efficiency through technological development, capital formation, employment creation and hence economic growth. The export-led growth has been the focus of Ethiopian economic policy since 1992.

This manuscript focuses on two macroeconomic indicators (real GDP and real export) to explain the causality between Ethiopian export performance and economic growth. Since 2003, these macroeconomic indicators trended upward. However, before 2003, the trend was inconsistence for both variables. GDP increased rapidly since 2003. The average $7 \%$ per annum economic growth rate caused significant change in GDP value. In Ethiopia in the early 1990s, the export

* Corresponding author:

hailegiorgisbiramo@yahoo.com (Hailegiorgis Biramo Allaro)

Published online at http://journal.sapub.org/economics

Copyright (C) 2012 Scientific \& Academic Publishing. All Rights Reserved growth rate was not stable due to the world price drop at the time. The value of exports, which relied mainly on primary products, was shown sign of change after 2003 when the new government reformed several policies including fiscal, monetary, and trade procedures that diversified exports. The years between 1992 and 2003 could be considered as transitional for the export sector, which moved from reliance on mainly traditional commodities to more diversified commodities. The effect of exports on GDP is not direct and simple to understand [World Bank, 2006].

The manuscript is organized as follows: section 2, presents a brief review of literature. Section 3, develops the model to be estimated, in section 4 , results and discussions were undertaken and section 5, conclusions.

\section{Literature Review}

In the 1950s and 1960s, many Latin America and Asian countries, such as Chile, Peru, Argentina, India and Pakistan followed ISI strategy. By the late 1960s, African countries such as Ethiopia, Nigeria and Zambia began to pursue a similar strategy [Singer, 1950; Prebisch, 1950]. Theories by the structuralists [Singer, 1950; Prebisch, 1950] provided justification for a protectionist policy (SI) by considering the division of the world into a centre (the developed countries), and a periphery (the developing world), where trade acted as a source of impoverishment in the latter and as a source of enrichment in the former. According to these theories, trade 
brings growth for the industrialized countries with little or no gain at all for the developing countries. Some studies [Ocampo, 1986; Ocampo and Taylor, 1998] have also expressed their concerns on the ground that in return to the 'modest' benefit of liberalization; a country may have to pay a higher price in terms of slow productivity growth, worsening income distribution, and likely de-industrialization. According to Deraniyagala and Fine (2001), import liberalization strategy is less attractive for export expansion to generate positive influence on growth. They disclosed that, if selective protection is done properly, will be more efficient than complete trade liberalization.

Marxist writers went further and said that poor countries should not trade at all with the so-called "north" [Redding, 1999]. The principal reason for protection and thus inward-looking strategy is the infant industry argument [Bardhan, 1970] that underlines the need for protecting firms at the beginning of their lifetime. Traditional trade models [Dornbusch and Samuelson, 1977; Rodriguez, 1974] moreover, considered the possibility of an optimal level of protection for a country that could influence the terms of trade. It has also been shown that protection can raise income when there is no full employment (Brecher, 1974 and 1992, as cited in [Vamvakidis, 2002]. In spite of these anti-trade theories, there exists a vast literature on the links between trade and economic growth and development.

However, after years of implementation, IS failed to act as an appropriate trade development strategy. Since then the idea of export expansion strategy gained popularity as a major determinant of economic growth for developing countries. Thus, ISI was eventually replaced by an outward-looking export promotion policy similar to that which the four Asian "tiger" countries adopted (Todaro \&Smith, 2006). From 1960s on, in the developing countries export activities were widely considered as a path to industrialization and instruments that useful in boosting economic growth [Krugman \& Obstfeld, 2003].

A lot of literature consists of analysis and testing of the outward-oriented export promotion policy or Export-Led Growth (ELG) hypothesis. This hypothesis states that promotion of the export sector is the best way to achieve economic growth. There are many explanations as to why exports are a crucial way to obtain growth [Giles and Williams, 2000; Santos-Paulino, 2000]. According to Giles and Williams [2000], export stimulates growth in a number of ways. These include supply/production and demand linkages, economies of scale (due to larger international markets), increased efficiency, adoption of superior technologies (embodied in foreign-produced capital goods), learning effects and improvement of human resources, increased productivity (through specializations and creation of employment).

The demand-side argument is that domestic markets severely limit the scope for sales of a domestically produced product, and that exports open domestic industries up to foreign markets, hugely increasing the potential demand for the product. This increase in potential market size can lead to increasing returns, while the home market may have been too small to achieve optimal scale. The economies of scale that can be achieved from exporting lead to increased capacity utilization, which results in greater product variety and productivity gains. Greater exposure to world markets may induce competitive pressures and may spur innovation and facilitate technological advancement and knowledge spill over's into the domestic economy, that lead to technological upgrading and efficiency gains in production and management practices [Giles and Williams, 2000].

Exports also generate much-needed foreign exchange, which can be used to provide the public funds needed to divert production towards the most growth-enhancing industries. This specialization towards more productive export industries and away from relatively inefficient sectors increases human capital through an increase in the general skill level of the country. Another argument for the ELG hypothesis is that it may be seen as part of the product and industry life cycle hypothesis. This hypothesis describes the economic growth as a cycle that begins with exports of primary goods. Over time, economic growth and knowledge change the structure of the domestic economy, including consumer demand, which propels the more technology-intensive domestic industry to begin exporting. As domestic demand ebbs, economic growth arises from technologically advanced exports. Evidence of this effect, which will be cited quite regularly, comes in Giles and Williams [2000].

According to Krugman and Obstfeld, 2006, exports may benefit export growth through generating positive externalities on non-exports, increased scale economies, improved allocative efficiency and better ability to generate dynamic comparative advantage. Exports ease foreign exchange constraints and can thereby provide greater access to international market. The foreign exchange earnings from exports allow the import of high quality intermediate inputs, mainly capital goods, for domestic production and exports, thus expanding the economy's production possibilities [Krugman and Obstfeld, 2006].

Whilst practical evidence in support of export-led growth (ELG) may not be universal, rapid export growth has been an important feature of East Asia's remarkable record of high and sustained growth. In particular, the wave of growth in the four tigers (Hong Kong, South Korea, Singapore and Taiwan) and the Newly Industrialized Countries (such as Malaysia, Indonesia and Thailand) has been used to support the argument that carefully managed openness to trade through an ELG is a mechanism for achieving fast growth. The experiences of these countries have provided the impetus to the neoclassical economists' view that ELG strategy can lead to growth [Todaro \&Smith, 2006].

The subject of ELG can as well be approached from the wider debate on openness (or trade) and growth. What appears to be gaining currency in recent years from crosscountry growth differences is that most of the countries pursuing growth successfully are also the ones that have taken most advantage of international. These countries have 
experienced high rates of economic growth in the context of rapidly expanding exports and imports trade [Martin, 2001; Masson, 2001]. During the past twenty years, in accordance with export promotion strategy, numerous empirical studies of causation of exports and economic growth have been conducted on the economies of developing countries, using either cross-section or time-series analysis. The first group of studies including [Michaely, 1977; Feder, 1982; and Kavoussi, 1984]; employed cross-country data sets and concluded that the positive correlation between export growth and GDP growth was seen as an evidence of ELG hypothesis. However, Medina - Smith [2001] and AbuQuarn and Abu Bader [2005] stated that this does not imply anything about the causality running from export growth to GDP growth or vice versa. More importantly, some studies, [Herzer et al., 2004] emphasis that utilizing cross-country data sets implicitly assumes that countries have similar economic structure and similar production technologies that might give us misleading results.

After all these criticisms, since the mid-1980s, Granger causality tests frequently have been used to find the relationship between export and economic growth [Gübe, 1997]. These studies began to employ Granger causality tests using individual country time series data sets. In view of the fact that, causality tests are very sensitive to the omitted variables, the empirical results are mixed and conflicting. Moreover, due to the national income accounting identity, export is a component of GDP. Hence, this means that there is biasness in favor of correlation. ELG hypothesis could be held for the certain export categories. The first study, using this methodology, was conducted by Jung and Marshall [1985]. They investigated the causal relationship between export and growth for 37 countries and found that export promotion policies just supported in 4 countries. Darrat [1987] investigated the ELG hypothesis for South Korea, Singapore, Hong Kong and Taiwan for the period 1955-1982. Although his findings indicated a positive relationship between export growth and economic growth under the investigated period, Granger causality test results did not support the ELG hypothesis for the three countries except for Korea.

There are some studies done about the recent Indian economic development whether this is caused by an increase in export. Nidugala [1991] attempted to find an answer whether the Indian economy is moving in the right direction as far as economic growth is concerned. He found that export growth played a significant role in the shift in the GDP growth in 1980s, cointegration between the real GDP and the real export for all countries. Ghatak et al., [1997], tested ELG for Malysia and he stresses that certain types of export could cause GDP growth yet this may not be found at the aggregate level of export. Ekanayake (1999) disclosed the ELG hypothesis for eight Asian developing countries for different time periods. He employed cointegration and error-correction modeling techniques to investigate whether ELG hypothesis holds for these countries in concerned time period. He found that there exists bi-directional causality between export growth and GDP growth for all eight Asian countries except for Malaysia. The evidence supports short run Granger causality running from economic growth to export in all cases except for Sri Lanka. Nevertheless, the strong evidence for long run Granger causality running from export growth to economic growth in all cases also exists.

The ELG hypothesis has also been tested by a number of studies in Turkey. One of these studies carried out by Özmen vd. [1999] using the quarterly data during the period 1983:11997:2. They have tested the causality issue between export and output by applying the standard Granger [1969] causality method. The results show uni-directional causality from export to output under the consideration period. The ELG hypothesis is also tested by Alıc1 and Ucal [2003] using quarterly data 1987:1-2002:4. They employed Toda and Yamamoto [1995] causality technique to test the hypothesis. The results indicate uni-directional causality running from export growth to output growth. Another study supporting the ELG hypothesis, using Johansen's methodology, is carried out by Doğanlar and Fisunoğlu [1999]. This study investigates the causal relationship between export and economic growth for seven Asian countries including Turkey for the period 1951-1995. They found that there is a bi-directional causality relationship between export and output growth for Turkey in long-run.

In the two recent studies, ELG hypothesis is investigated Latin American countries. Herzer et al. [2004], using Chilean time series data 1960-2001, employed single equation and system cointegration techniques to analyze the productivity effects of manufactured and primary exports. They found that exports of manufactured products are important for productivity and therefore for long-run economic growth. Zuniga [2000] investigated the export-led growth for Honduras and five other Latin American countries. He employed real GDP, real gross capital formation, labor in numbers and real exports for the 1970-2000 periods. His findings support ELG hypothesis only in El Salvador in short run and totality cases.

In a recent study, Sharma and Panagiotidis [2004] investigated the export rise in India for the period 1971-2001. They employed Engle-Granger causality and Johansen methodologies to test whether export and GDP are cointegrated and export growth leads to the GDP growth. The authors utilized real GDP, real net GDP (subtracted from export), real export, real import and real investment, population and employment in the formal sector. They failed to find the cointegration between both types of GDP and export. They also could not show that exports Granger causes for both GDP with exports and GDP without exports.

The ELG hypothesis is also tested for Asian developing countries. Rahman and Mustafa [1997] selected 13 Asian developing countries for different time periods. They included real GDP and real exports in their equation. They applied Granger causality test, and cointegration and error-correction models. They found Guatemala and for non agricultural sector of Honduras. Exports Granger causes economic growth in the long run and in totality for Nicaragua. For Costa Rica, Honduras and agricultural GDP sector of 
Honduras, the ELG hypothesis could not be supported.

Thus, much has been said in the literature regarding the role of the Export- Led Growth (ELG) to the overall economic performance. Therefore, it can be concluded from above discussions, that the empirical evidence has been rather mixed. While some studies support a causal linkage between exports and economic growth, others failed to support the existence of a significant relationship between these two variables [Shan and Sun, 1998].

\section{Methodology}

In multivariate time-series analysis, causality test is done to check which variable causes (precedes) another variable. Given two variables $\mathrm{X}$ and $\mathrm{Y}, \mathrm{X}$ is said to Granger cause $\mathrm{Y}$ if lagged values of $X$ predict $Y$ well. If lagged values of $X$ predict $Y$ and at the same time lagged values of $Y$ predict $X$, then there is a bi-directional causality between $\mathrm{X}$ and $\mathrm{Y}$. According to Granger [1969], a variable X (in this case export) is said to be Granger cause another variable Y (GDP) if past and present values of export help to predict GDP. Four patterns of causality can be distinguished: (a) unidirectional causality from $\mathrm{X}$ to $\mathrm{Y}$; (b) unidirectional causality from $\mathrm{Y}$ to $\mathrm{X}$; (3) feedback or bi-directional causality; and (d) no causality. A simple Granger causality test involving two variables, exports and GDP can be written as:

$$
\begin{gathered}
X_{t}=\sum_{j=1}^{p} \alpha_{j} x_{t-j}+\sum_{j-1}^{p} \varphi y_{t-j}+u_{t} \\
Y_{t}=\sum_{j=1}^{p} \delta_{j} x_{t-j}+\sum_{j-1}^{p} \Psi y_{t-j}+v_{t}
\end{gathered}
$$

where, $x, y, t$, and $p$ are export, GDP, time and lag order respectively. Two null hypotheses to be tested are:

$\mathrm{H}_{0}: \alpha_{j}=0, j=1 \ldots p \quad$, export growth does not cause GDP growth

$\mathrm{H}_{1}: \delta_{j}=0, j=1 \ldots . p$, export growth causes GDP growth.

At estimation stage taking logs of the variables in equation (1) and (2) and differentiating with respect to time gives the following equations:

$$
\begin{aligned}
& \log X_{t}=\alpha_{0}+\alpha_{j} \log x_{t-j}+\varphi_{j} \log y_{t-j}+u_{t} \\
& \log Y_{t}=\mu_{0}+\delta_{j} \log x_{t-j}+\Psi_{j} \log y_{t-j}+v_{t}
\end{aligned}
$$

If the causality test does not reject all the hypotheses, it means that export growth does not cause GDP growth and GDP growth also does not cause exports growth, it suggests that the two variables are independent of each other. If the first hypothesis is rejected, it indicates that exports growth causes GDP growth. Rejection of the second hypothesis means that the causality runs from GDP to exports. If the Granger causality test rejects all hypotheses, there is bi-directional causality between exports and GDP.

\section{Results and Discussion}

\subsection{Descriptive Statistics Analysis}

A correlation matrix analysis Table (1) was performed to investigate the correlation between variables (real GDP and real export). The results illustrated a significant and strong positive correlation between variables with two lags. However, strong correlation does not imply causation from one variable to another (causation from export to GDP or vice versa).

Table 1. correlation matrix

\begin{tabular}{ccc}
\hline Variables & Export & GDP \\
Export & 1.000000 & 0.916490 \\
GDP & 0.916490 & 1.000000 \\
\hline
\end{tabular}

Therefore, in the following section the two methods commonly used in a time-series analysis were examined in accordance with validity of export performance on economic growth. Econometric techniques such as stationarity test and Granger causality test were employed to find short-run relationship, long-run relationship, and direction of causality between export performance and economic growth.

\subsection{Econometric Analysis}

\subsubsection{Unit Root Tests}

Unit root tests were conducted first, with real GDP and real export as the time series variables. These variables must be stationary or cointegrated in order to avoid a spurious regression situation and to ensure whether they are stationary or not. Augmented Dickey-Fuller (ADF) test was conducted with critical value of $5 \%$ and $10 \%$ applied for test. The results of the unit root test for Ethiopian annual data (1974-2009) on two series (real GDP and real export) shows that the ADF test result indicated that the two series are non-stationary at levels, i.e., the results failed to reject the null hypothesis. Thus, to correct for the presence of unit root in the series, first and second difference measures were taken. The results of the unit root tests in the first and second difference based on ADF test showed that, the series were stationary in the first and second difference. Therefore, the variables were found to be integrated in order of 1 and 2 in the models with a trend. Critical values for tests were found to be -3.10 and -2.69 at $5 \%$ and $10 \%$ respectively.

\subsubsection{Granger Causality Test}

The causal relationship between export and economic growth of the country was analyzed with the application of Granger (1969) causality test using annual data for the period 1974 to 2009. Table (1) indicates the hypothesis that export does not Granger causes GDP is rejected, while the hypothesis that GDP does not Granger causes an export is accepted. These results provide evidence of uni-directional causality between export and GDP. This implies that export growth causes economic growth and visversa. These results provide evidence in support of the export-led growth hy- 
pothesis and as well as the existence of reverse causality. The findings also suggest that there is a need to promote export expansion policies in order to achieve high economic growth. Correspondingly, there is also a need to devote resources on the production of non-export goods in order to increase exports.

Table 1. Granger causality test results

\begin{tabular}{cccc}
\hline \multicolumn{4}{c}{$\begin{array}{c}\text { Sample: 1974 2009 } \\
\text { Lags: 2 } \\
\text { Observation:34 }\end{array}$} \\
\hline \hline Null Hypothesis: & F-Statistic & Probability & Remark \\
\hline \hline $\begin{array}{c}\text { GDP growth does not cause } \\
\text { export growth }\end{array}$ & 1.01130 & 0.37622 & accept \\
$\begin{array}{c}\text { Export growth does not cause } \\
\text { GDP growth }\end{array}$ & 5.73319 & $0.00798^{*}$ & Reject \\
\hline
\end{tabular}

\section{Conclusions}

The study examined the current issue of accelerated economic growth in Ethiopia. The causal relationship between export and economic growth of the country was analyzed with the application of Granger [1969] causality test using annual data for the period 1974 to 2009 . It revealed that the decline in economic growth in the country pre reform period coupled with the alarming population growth led to stagnation and even a continual decline in the income of the country. This led to closer scrutiny of export growth on economic growth to achieve a sustained economic growth. Since 1992, the economic growth policy of Ethiopian government was guided by the idea of export-led growth. The view of export-led growth conceives growth of exports as having a favorable impact on economic growth. According to this view, export expansion to foreign markets improves resource allocation and production efficiency. Export is claimed as the 'engine of growth'. The results of the study show that there is evidence of uni-directional causality between export and economic growth for Ethiopia. Export growth causes economic growth and visversa. Thus, the results are favorably comparable to those obtained in the literature [Shan and Sun, 1998].

However, the idea of export-led growth was anchored on the Washington consensus which emphasizes policies of trade liberalization, privatization, market flexibility, capital mobility and fiscal austerity programs. In the context of least developing countries these policies have been severely criticized. As pointed out in the literature, the export-led growth paradigm shifted the focus away from domestic market growth and placed emphasis on the international market in which developing countries are found in "race-to-the-bottom" competition with each other. In countries where the structural transformation has not yet realized shifting ever more output onto global markets can distort development. Another criticism refers to the instability and fluctuation of the country's export earnings as a result of the competition among countries and downward price pressure. Rivalry between countries at global markets often crowded out exports of another country. If more countries competing with each other, export-led development can have a zero-sum game effect (one is gaining at the expense of the other). Under such a competition circumstance increasing exports certainly distorts internal development. Other identified problem of the strategy is its weak linkages into the rest of the economy. Export- led growth is considered by some as a means of extracting surplus to the extent of negatively affecting local people interest. Export-led growth is viewed to have similar exploitative characteristics of an earlier "plantation" model of development [Palley, 2002].

In contrast to the export-led growth hypothesis, there is a development strategy which emphasis growth based on deep internal market development. This paradigm is commonly known as domestic demand-led growth. The fundamental idea of demand-led growth is that growth in output is determined by the growth in aggregate demand. The focus of this development strategy is on domestic development and identification of policies, which influence the level and growth of aggregate demand. In the context of least developing countries, the paradigm emphasis internally generated economic growth, i.e., shift in demand and an increase in domestic investment and technological improvement. Once a certain level of domestic industrialization is achieved through demand-led growth strategy, the country enhances its international competitiveness of tradable goods. The history of the industrialized economies shows such sequences along the path of development. The main argument of this strategy is that instead of focusing to grow on the back of demand expansion in other countries, at the early stage of development, it is much better to produce for the domestic market since this creates rapid employment and provides sustained household income. Theoretically speaking, under demand-led growth the capacity of the economy to supply output expands in response to an increase in the level of effective demand.

\section{ACKNOWLEDGEMENTS}

I gratefully acknowledged the anonymous reviewers

\section{REFERENCES}

[1] Abu-Quarn, A. S and S. Abu-Bader, 2005. "The Validity of the ELG Hypothesis in the MENA Region: Cointegration and Error Correction Model Analysis," Applied Economics, 36:685-1695.

[2] Alıc1, A.A and M. Ş. Ucal. 2003. "Foreign Direct Investment, Exports and Output Growth of Turkey: Causality Analysis," European Trade Study Group (ETSG) Fifth Annual Conference, (September), Madrid.

[3] Bardhan, P.K., 1970. Economic Growth, Development and Foreign Trade, New York: Wiley.

[4] Brecher, A. R., 1992. "An Efficiency-Wage Model with 
Explicit Monitoring: Unemployment and Welfare in an Open Economy", Journal of International Economics, vo.32, pp.179-91.

[5] Brecher, A. R., 1974. "Optimal Commercial Policy for a Minimum-Wage Economy", Journal of International Economics, vol.4, pp. 139-49.

[6] Darrat, A.F., 1987. "Are exports an Engine of Growth? Another Look at the Evidence" Applied Economics, vol. 19, pp.277-83.

[7] Deraniyagala, S. and Fine, B., 2001. "New Trade Theory versus Old Trade Policy: A Continuing Enigma", Camnbridge Journal of Economics, vol.25, Pp.809-25.

[8] Doğanlar, M and M. Fisunoğlu. 1999. "Causality Between Exports and Economic Growth in Asian Countries," Yap1 Kredi Economic Review, 10(11):3-11.

[9] Dornbusch, R., Fischer, S. and Samuelson, P., 1977. "Comparative Advantage, Trade and Payments in a Ricardian Model with a continuum of Goods", American Economic Review, vol.67, No.5, pp.823-839.

[10] Ekanayake, E. M. 1999. "Exports and Economic Growth in Asian Developing Countries: Cointegration and Error-Correction Models," Journal of Economic Development, 24(2):43-56.

[11] Feder G., 1982. On Exports and Economic Growth; Journal of Development Economics, Vol. 12, 59-73.

[12] Ghatak, S., Milner, C. and Utkulu, U., 1997. "Exports, Export Composition and Growth: Cointegration and Causality Evidence for Malaysia", Applied Economics, vol. 29, 213-23.

[13] Giles, J. and Williams, C., 2000. Export-led growth: a survey of the empirical literature and some non causality results: Part 1. Econometrics Working Paper, EWP0001.

[14] Granger, C.W.J., 1969. Investigating the Causal Relations by Econometric Models and Cross-Spectral Methods. Econometrica, 37(3): 424-238.

[15] Gübe, Y., 1997. "İktisadi Büyüme ve İhracat Performansı," Hazine Dergisi, 6:17-28.

[16] Herzer, D., F. N. Lehmann and B. Siliverstovs. 2004. "Export-Led Growth in Chile: Assessing the Role of Export Composition in Productivity Growth," Ibero-America Institute for Economic Research Discussion Papers.

[17] Jung, W.S. and P.J. Marshall, 1985. Exports, Growth and Causality in Developing Countries; Journal of Development Economics 18, 1-12.

[18] Kavoussi, R.M., 1984. "Export Expansion and Economic Growth: Further Empirical Evidence", Journal of Development Economics, vol.14, pp.241-250.

[19] Krugman Paul R., and Obstfeld Maurice, 2006. Applied time-series econometrics. Cambridge: Cambridge University Press.

[20] Krugman Paul R., and Obstfeld Maurice, 2003. International economics, theory and policy $6^{\text {th }}$ eds. Copyright (C) 2003 by Paul R. Krugman and Maurice Obstfeld.

[21] Masson, P., 2001. "Globalization: facts and figures". IMF Policy Discussion Paper, PDP/01/4. Washington DC: IMF.
[22] Martin, W., 2001. "Trade policies, developing countries and globalization". Development Research Group. Washington DC: World Bank.

[23] Medina-Smith, E. J. 2001. "Is the Export Led Growth Hypothesis Valid for the Developing Countries? A Case Study for Costa Rica," Policy Issues in International Trade and Commodities, Study Series Number 7, United Nations Conference on Trade and Development.

[24] Michaely M., 1977. Exports and growth: An empirical investigation. Journal of Development Economics, 4:49-53, March.

[25] Nidugala, G. K., 1991. "Exports and Economic Growth in India: An Empirical Investigation," The Indian Economic Journal, 47(3):67-78.

[26] Ocampo, J. A. and Taylor, L., 1998."Trade Liberalization in Developing Economies: Modest Benefit but Problem with Productivity Growth, Macro Prices and Income Distribution", Economic Journal, vol.108, 1523-46.

[27] Ocampo, J.A., 1986. "New Developments in Trade Theory and LDCs", Journal of Development Economies, 22: 129-70.

[28] Özmen, A, M. Özer and S. Türkyılmaz, 1999. "Türkiye'de İhracat ve Economic Büyüme Arasındaki Nedenselliğe İlişkin Bir Uygulama Denemesi," Orhan Oğuz'a Armağan, Marmara Üniversitesi Yayını, No. 640:379-392.

[29] Palley, T.I., 2002. A new development paradigm: domestic demand-led growth, discussion paper, foreign policy in focus, Albuquerque, Newq Mexico.

[30] Prebisch, Y., 1950. "The Economic Development of Latin America and Its Principal Problems", Economic Bulletin for Latin America, vol.7, pp. 1-22.

[31] Rahman, M and M. Mustafa. 1997. "Dynamics of Real Exports and Real Economic Growths in 13 Selected Asian Countries," Journal of Economic Development, 22(2):81-95.

[32] Redding S., 1999. "Dynamic Comparative Advantage and Welfare Effects of Trade", Oxford Economic Paper, vol.51, pp.15-39.

[33] Rodriguez, C. A., 1974. "The non-equivalence of tariffs and quota under retaliation", Journal of International Economics, vol. 4, pp.295-98.

[34] Redding S., 1999. "Dynamic Comparative Advantage and Welfare Effects of Trade", Oxford Economic Paper, vol.51, pp.15-39.

[35] Rodriguez, C. A., 1974. "The non-equivalence of tariffs and quota under retaliation", Journal of International Economics, vol. 4, pp.295-98.

[36] Santos-Paulino, A. U. 2000. "Trade Liberalization and Export Performance in Selected Developing Countries" Department of Economics, Studies in Economics, No. 0012 University of Kent, Canterbury.

[37] Sharma, A. and T. Panagiotidis, 2004. "An Analysis of Exports and Growth in India: Cointegration and Causality Evidence (1971-2001)" Review of Development Economics, Vol. 9: 232-248.

[38] Singer, H. W., 1950. The Distribution of Trade Between Investing and Borrowing Countries, American Economic 
Review, 40, May, pp. 470-485.

[39] Sun, F. and Shan, J., 1998. Export-led Growth and the US Economy: Another Look. Applied Economic Letters, 3: 341-344.

[40] Toda, H.Y and T. Yamamoto. 1995. "Statistical Inference in Vector Auto regressions with Possibly Integrated Processes," Journal of Econometrics, 66:225-250.

[41] Todaro, M.P. and Smith, S.C., 2006. Economic development. London: Pearson-Addison Weasley.
[42] Vamvakidis, A., 2002. "How Robust is the Growth- Openness Connection? Historical Evidence", Journal of Economic Growth, vol.7, pp.57-80

[43] World Bank, 2006. World Development Report: Equity and Development. Washington, DC. World Bank.

[44] Zuniga H. C. 2000. "Export-Led Growth in Honduras and the Central American Region," Master Thesis, The Department of Agricultural Economics and Agribusiness, Louisiana State University. http://etd.lsu.edu/docs/available/etd-12032004070104/unrestricted/Final_Thesis_Document.pdf (Accessed 25.01.2005). 